\author{
AGNIESZKA KWIATEK \\ Zakład Wirusologii Molekularnej \\ Instytut Mikrobiologii \\ Wydziat Biologii \\ Uniwersytet Warszawski \\ Miecznikowa 1, 02-096 Warsaw \\ E-mail: akwiat@biol.uw.edu.pl
}

\title{
PROPERTIES AND PATHOGENESIS OF CORONAVIRUSES
}

\section{INTRODUCTION}

Over the past two decades, three coronaviruses have appeared around the world and caused epidemics that have caused significant health dismay in the world: SARS-CoV, MERS-CoV and SARS-CoV-2. These viruses are highly pathogenic zoonotic viruses, while other coronaviruses that infect humans cause mainly mild, asymptomatic infections.

SARS-CoV emerged in Guangdong, China in 2002, MERS-CoV in Arabian Peninsula in 2012, and SARS-CoV-2 was discovered in December 2019 in Wuhan,
China. SARS-CoV-2, the etiological factor of coronavirus disease 2019 (COVID-19), emerged in China and has spread globally causing a pandemic with more than 15785641 cases and 640016 deaths as per July 26, 2020.

\section{CLASSIFICATION OF CORONAVIRUSES}

SARS-CoV, MERS-CoV, and SARS-CoV-2 are members of Betacoronavirus genus, which is included to Orthocoronavirinae subfamily and Coronaviridae family, likewise HCoV-HKU-1, and HCoV-OC43. Human coronavirus 229E (HCoV-229E) and $\mathrm{HCoV}-$

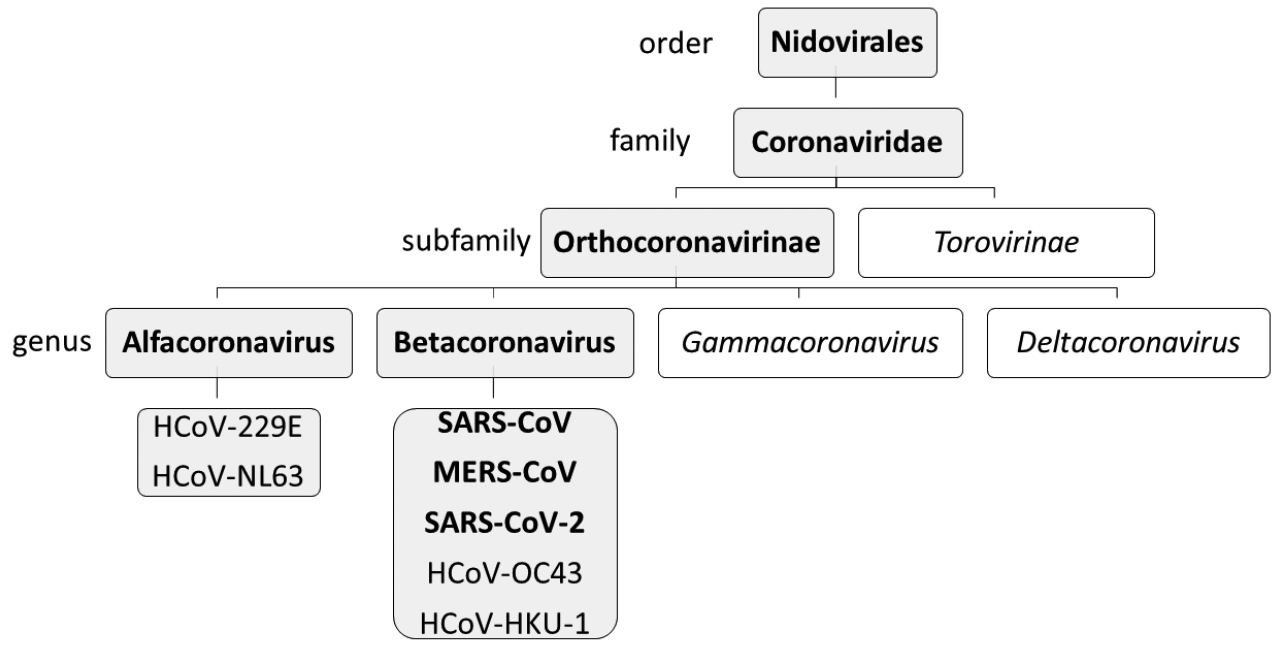

Figure 1. Classification of Coronaviruses. Grey rectangles include the names of taxa of human coronaviruses. Additionally, the taxa names are bolded. 
NL63 represent Alfacoronavirus genus. No human-infecting virus has been classified in Gammacoronavirus and Deltacoronavirus (Fig. 1).

\section{STRUCTURE OF BETACORONAVIRUS VIRION AND PHYSICOCHEMICAL PROPERTIES}

The virus particles have diameter of 60$140 \mathrm{~nm}$ and appear round or oval with spikes projecting from the surface of the virus giving the appearance of a solar corona, prompting the name, coronaviruses. The spikes are anchored in phospholipid bilayer envelope. Among the $\mathrm{S}$ (spike) proteins, in the virus envelope, the membrane (M) proteins and the envelope (E) proteins are anchored. Within the envelope there is the helically symmetrical nucleocapsid, composed of genomic RNA and phosphorylated nucleocapsid $(\mathrm{N})$ protein (NEUMAN et al. 2011).

Most of the knowledge about the physicochemical properties of coronaviruses comes from SARS-CoV and MERS-CoV. Viral particles are sensitive to heat, lipid solvents, non-ionic detergents, formaldehyde, oxidizing agents and UV irradiation, but highly resistant to bile salts $(0.1 \%$ deoxycholate) and extreme $\mathrm{pH}$ conditions (infectivity not affected by exposure to $\mathrm{pH}$ values between 2.5 and 10.3). SARS-CoV-2 can be inactivated by UV or heating at $56^{\circ} \mathrm{C}$ for $30 \mathrm{~min}$, and is also sensitive to most disinfectants such as diethyl ether, $75 \%$ ethanol, chlorine, peracetic acid, and chloroform. It has been reported that SARS-CoV-2 was more stable on plastic and stainless steel than on copper and cardboard, and viable virus was detected up to $72 \mathrm{~h}$ after application to these surfaces. On cardboard, the half-life of SARS-CoV-2 was longer than that of SARS-CoV and the longest viability of both viruses was on stainless steel and plastic (VAN DOREMALEN et al. 2020).

\section{GENOME OF CORONAVIRUS}

There is an overall similarity in genome structure and nucleotide sequence between coronavirus genomes. The genome of Coronavirusis consist of $\sim 30 \mathrm{~kb}$, single and positive stranded RNA. Coronaviruses have the largest genome among the RNA viruses.

The coronavirus genome contains a $5^{\prime}$ cap structure along with a $3^{\prime}$ poly (A) tail, allowing it to act as a mRNA for translation of polyproteins. The coding sequence is flanked by 5' and 3' untranslated regions (UTRs). The genome structure is as follows: the $5^{\prime}$ proximal part, more than two- thirds of the genome, comprises ORF1a and ORF1b encoding orf $1 \mathrm{ab}$ polyproteins, while the $3^{\prime}$ one third consists of genes encoding structural proteins including $\mathrm{S}, \mathrm{E}, \mathrm{M}$, and $\mathrm{N}$ proteins.

The major distinction between SARSCoV-2 and SARS-CoV is in orf3b, spike and orf8, being especially variable in spike S1 and orf8, which were previously shown to be recombination hot spots (CHAN et al. 2020). Additionally, the SARS-CoV-2 genome includes ORF3a, ORF6, ORF7a, ORF7b, and ORF8, ORF10 genes encoding accessory proteins.

\section{PROTEINS OF BETACORONAVIRUS}

The 1200 amino acid long spike (S) receptor protein is a homotrimer protruding from the viral surface which mediates pathogen entry into host cells. The angiotensinconverting enzyme 2 (ACE2) is the cognate cellular receptor for spike protein of SARS$\mathrm{CoV}$ and SARS-CoV-2. The SARS-CoV-2 spike glycoprotein, shares $76 \%$ amino acid sequence identity with spike protein of human SARS-CoV Urbani and $80 \%$ with those of bat SARSr-CoV ZXC21 and ZC45 (WALLS et al. 2020).

The $\mathrm{S}$ protein monomer is composed of two subunits $\mathrm{S} 1$ and $\mathrm{S} 2$. N-terminal S1 subunit recognizes ACE2 receptor by a conserved Receptor Binding Domain, including Receptor Binding Motif. The S2-membraneanchored subunit of spike glycoprotein is responsible for fusion of viral envelope with cellular membranes. In the structure of S2subunit, the fusion peptide, a second proteolytic site, an internal fusion peptide and two heptad-repeat domains preceding the transmembrane domain are distinguished (WALls et al. 2020, COUTARD et al. 2020, SHANG et al. 2020).

The surface of the spike protein is dominated by host-derived glycans with each trimer displaying N-linked glycosylation sites. These oligosaccharides play a role in protein folding (influence on priming $\mathrm{S}$ protein by host proteases) and immune evasion (modulation of antibody recognition) (WATAN$\mathrm{ABE}$ et al. 2020).

Envelope (E) and membrane (M) proteins are another viral molecules anchored in the viral envelope.

$\mathrm{E}$ protein is a small $76-109$ amino acids molecule, which contains hydrophilic 7-12 amino acids terminus, hydrophobic transmembrane domain (TMD) of 25 amino acids, and hydrophilic carboxyl terminus. The hydrophobic region of the TMD contains at least one predicted amphipathic a-helix that oligomerizes to form an ion-conductive pore 
in membranes. The $\mathrm{E}$ protein can interact with other viral proteins, e.g. with viral $M$, $\mathrm{N}$ and $\mathrm{S}$ proteins. The $\mathrm{E}$ protein is engaged in several aspects of the virus replication cycle, such as assembly, budding, envelope formation, and pathogenesis. Absence or inactivation, of $\mathrm{E}$ protein results in attenuation of viruses, due to alterations in either virion morphology or tropism. Besides its morphogenetic role, $\mathrm{E}$ protein can function as viroporin with membrane permeabilizing activity facilitating virus release from infected cells (SCHOEMAN and FIELDING 2019).

The $\mathrm{M}$ protein, $\sim 25-30 \mathrm{kDa}$, of SARS$\mathrm{CoV}$ and MERS-CoV is the most abundant structural protein present on viral envelope, with N-terminal glycosylated ectodomain and C-terminal endodomain. This dimeric protein can adopt two conformations. Elongated $\mathrm{M}$ protein form is connected with rigidity, clusters of spikes and a relatively narrow range of membrane curvature, while compact $M$ protein form promotes flexibility and low spike density. Thus, $M$ protein participates in the defining the shape of the vi- ral envelope. By interaction with other viral proteins, $M$ protein is engaged in replication and assembly of viral particles. Cooperating with $\mathrm{N}$ proteins, $\mathrm{M}$ protein stabilizes the nucleocapsid and the internal core of virions and participates in the viral assembly. Interaction of $\mathrm{M}$ protein with spike glycoprotein ensures the retention of $S$ in the ERGolgi intermediate compartment (ERGIC)/ Golgi complex and its incorporation into new virions. Together with $\mathrm{E}$ protein, $\mathrm{M}$ protein composes the viral envelope and interaction between $\mathrm{M}$ and $\mathrm{E}$ proteins is sufficient for virus particle formation and release of virus-like particles (VENNEMA et al. 1996, NEUMAN et al. 2011, EsCORS et al. 2001).

The nucleocapsid protein (N) consists three highly conserved parts: a N-terminal RNA-binding domain (NTD), a C-terminal dimerization domain (CTD), and an intrinsically disordered central Ser/Arg (SR)-rich linker for primary phosphorylation and potential interaction sites with other protein and protein-RNA partners. The primary functions of $\mathrm{N}$ protein are binding to the viral RNA ge-

Table 1. Functions of Betacoronavirus non-structural proteins (nsps).

\begin{tabular}{|c|c|}
\hline Protein & Function \\
\hline nsp1 & $\begin{array}{l}\text { inhibits host translation and gene expression by mRNA degradation and binding } 40 \mathrm{~S} \text { ribosome } \\
\text { subunit resulting in blocking innate immune response }\end{array}$ \\
\hline nsp2 & binds to prohibitin proteins, function not determined \\
\hline \multirow[t]{6}{*}{ nsp3 } & PL2pro multi-domain transmembrane protein, possessing: \\
\hline & ADRP activity, promotes cytokine expression; \\
\hline & PLPro/Deubiquitinase domain, cleaves viral polyprotein; \\
\hline & antagonist of IRF3 and NF-kB signaling resulting in blocking host immune response; \\
\hline & Ubl1 and Ac domains, interact with $\mathrm{N}$ protein; \\
\hline & Ub12, NAB, G2M, SUD, Y domains, unknown functions \\
\hline nsp4 & interacts with nsp3; induce the formation of double-membrane vesicles \\
\hline nsp5 & MoPro or 3CLpro processing of viral polyproteins \\
\hline nsp6 & potential transmembrane scaffold protein \\
\hline nsp7 & $\begin{array}{l}\text { forms hexadecameric nsp7-nsp8 complex, essential co-factor of nsp12, may act as processivity } \\
\text { clamp for RNA polymerase }\end{array}$ \\
\hline nsp8 & forms hexadecameric nsp7-nsp8 complex, essential co-factor of nsp12, may act as primase \\
\hline nsp9 & a single-stranded RNA binding protein \\
\hline nsp10 & $\begin{array}{l}\text { cofactor for nsp16 and nsp14, forms heterodimer with both and stimulates ExoN and S-adenosyl- } \\
\text { methionine-dependent (nucleoside-2'-O)-methyltransferase }\end{array}$ \\
\hline nsp12 & RNA-dependent RNA polymerase (RdRp) \\
\hline nsp13 & a superfamily 1-like helicase (HEL1), RNA helicase, 5' triphosphatase \\
\hline nsp14 & C-terminal domain functions as a (guanine-N7) methyl transferase (N7-MTase) for mRNA capping \\
\hline & N-terminal exoribonuclease (ExoN) domain displays a $3^{\prime}-5^{\prime}$ exoribonuclease proofreading activity \\
\hline nsp15 & NendoU, uridylate-specific endoribonuclease \\
\hline nsp16 & $\begin{array}{l}\text { S-adenosylmethionine-dependent (nucleoside-2'-O)-methyltransferase modifying the RNA cap at ri- } \\
\text { bose 2'-O positions }\end{array}$ \\
\hline
\end{tabular}


nome and packing them into a long helical nucleocapsid structure. Besides forming the nucleocapsid, $\mathrm{N}$ protein is involved in the regulation of viral RNA synthesis in replication/transcription, viral assembly and budding, resulting in complete virion formation. $\mathrm{N}$ protein also participates in host - pathogen interactions by impact on actin reorganization, host cell cycle progression, and apoptosis (CHANG et al. 2006). Similar as for SARS-CoV, $\mathrm{N}$ protein of SARS-CoV-2 is a highly immunogenic viral antigen, capable of inducing protective immune responses towards SARS-CoV-2 (ZENG et al. 2020, TANG et al. 2005).

A set of non-structural and accessory coronavirus proteins (nsps) are functioning in viral replication and interaction with the host cells (Table 1).

\section{REPLICATION OF BETACORONAVIRUS}

The interaction between viral $\mathrm{S}$ protein and its cognate cellular receptor is the primary determinant of host cell infection and controls viral tissue tropism. As mentioned above, ACE2 is the cognate cellular receptor for spike protein of SARS-CoV and SARSCoV-2 (WALls et al. 2020, HofFMANN et al. 2020b). Integrins, but not dipeptidyl peptidase 4 (DPP4) or aminopeptidase $\mathrm{N}$, may act as an alternative receptor for SARSCoV-2. MERS-CoV binds to cell surface by DPP4 (RAJ et al. 2013, OU et al. 2020, SIGRIST et al. 2020).

The viral attachment to the surface host cell is mediated by interactions between S1 subunit of the $\mathrm{S}$ protein and its human cellular receptor. Attachment of the viral $\mathrm{S}$ protein to the host receptors mediates endocytosis of the virus into host cell (WANG et al. 2008). In the next step of coronavirus replication, mediated by $\mathrm{S} 2$ subunit of the $\mathrm{S}$ protein, there occurs a fusion of virus phospholipid envelope with the endosomal membrane. Consequently, nucleocapsid is released into the cell cytosol, where further stages of the replication cycle take place.

To fuse membranes, the spike protein needs to be proteolytically activated. The SARS-CoV entry-activating proteases include cell surface protease TMPRSS2 and lysosomal protease cathepsin L (REINKE et al. 2017, Bosch et al. 2008, Ou et al. 2020, SIMMONS et al. 2005, QIAN et al. 2013). In the case of cell entry by SARS-CoV-2, the spike protein is additionally preactivated by pro-protein convertase furin. The inhibition of furin-dependent priming of $\mathrm{S}$ protein significantly decreases cell entry efficiency and reduces its dependence on the target cell proteases and thus has implications for the viral replication cycle and pathogenicity (SHANG et al. 2020, HOFFMANN et al. 2020a). The next step in the coronavirus replication cycle is the translation of the two polyproteins (pp1a and pplab) from ORF1a and ORF $1 b$ of the viral genomic RNA. Resulting polyproteins are proteolytically cleaved by virus-encoded proteases into 16 nonstructural proteins (nsp1-16) forming the replicase/transcriptase complex (RTC), that directs and coordinates processes leading to the replication and transcription of the coronavirus genome (SUBISSI et al. 2014). RTC is anchored in double-membrane vesicles (DMVs), which form coronavirus replication structures. These 200-300 $\mathrm{nm}$ membranous structures are derived from the endoplasmic reticulum or Golgi apparatus (SNIJDER et al. 2006).

The viral genome serves as the template not only for translation of pp1a and pp $1 \mathrm{ab}$ polyproteins, but also for RTC-mediated replication and transcription leading to the synthesis of negative-sense RNA intermediates. Negative-sense RNA intermediates are generated to serve as the templates for the synthesis of positive-sense genomic RNA (gRNA) and subgenomic RNAs (sgRNAs). A subset of 9 subgenomic RNAs, including those encoding all structural proteins, is produced through discontinuous transcription. These subgenomic $(-)$ RNAs are then transcribed into subgenomic (+)mRNAs involved in structural proteins translation. S, $\mathrm{E}$ and $\mathrm{M}$ structural proteins, inserted into the endoplasmic reticulum, move along the secretory pathway into the endoplasmic reticulum-Golgi intermediate compartment. There, viral genomes encapsidated by $\mathrm{N}$ protein bud into membranes of the ER-Golgi intermediate compartment containing viral structural proteins, forming mature virions. After an assembly, virions are transported to the cell surface in vesicles and released by exocytosis.

\section{TISSUE AND CELLULAR PATHOGENESIS OF SARS-COV-2}

As mentioned above, SARS-CoV-2 binds to ACE2, which primary physiological function is maturation of angiotensin, a peptide hormone, that controls vasoconstriction and blood pressure (LI et al. 2020b). The ACE2 is broadly expressed in cells of nasal mucosa, bronchus, lung, heart, oesophagus, kidney, stomach, bladder, and ileum. Therefore these human organs are all vulnerable to SARS-CoV-2 (Li et al. 2020a).

SARS-CoV-2 is transmitted predominantly via respiratory droplets, contact, and potentially in faecal-oral rout (PARK 2020). Pri- 
mary viral replication is presumed to occur in mucosal epithelium of upper respiratory tract, with further multiplication in lower respiratory tract. Few infections are controlled at this point and remain asymptomatic. Thus, patients may be asymptomatic, or experience mild, moderate or severe symptoms, presented with or without pneumonia (Dong et al. 2020).

Common signs and symptoms of SARSCoV-2 infected patients are: fever, cough, sputum production/expectoration, shortness of breath/dyspnoea, headache, sore throat/ pharyngalgia (ZHENG 2020). The pathological features of COVID-19 resemble those seen in SARS-CoV MERS-CoV infection (XU et al. 2020, Gu i KORTEWEG 2007).

The most important risk factors for a complicated course are advanced age, hypertension and chronic heart and lung diseases as well as the immune deficiencies. Some patients have also exhibited nonrespiratory symptoms such as acute liver and heart injury, kidney failure, diarrhoea, implying multiple organ involvement (SALZBERGER et al. 2020).

Major pathological finding in respiratory tract of SARS-CoV-2-infected patients include diffuse alveolar damage with varying degrees of acute exudative features including oedema and hyaline membranes and fibrosis. Interstitial mononuclear inflammatory infiltrates, dominated by lymphocytes, could be observed in lungs as well. In turn, multinucleated syncytial cells with atypical enlarged pneumocytes characterized by large nuclei, amphophilic granular cytoplasm, and prominent nucleoli identified in the intraalveolar spaces indicate viral cytopathic-like changes.

\section{MOLECULAR BASIS OF PATHOGENESIS OF SARS-COV-2}

Molecular pathogenesis takes into account the molecular alterations occurring in response to environmental factors, to produce pathology. It was demonstrated that SARS-CoV disturbs the expression of the host genes, modulates cell-cycle of infected cell or inhibits innate immune response (HUANG et al. 2011, BHARDWAJ et al. 2012, MINAKSHI et al. 2009, LINDNER et al. 2007, DEVARAJ et al. 2007, SiU et al. 2009). An affinity-purification mass spectrometry (APMS) analysis identified 332 high-confidence protein interactions between 26 SARS-CoV-2 proteins and human proteins, concerning several complexes and biological processes. These included DNA replication, epigenetic and gene expression regulators, vesicle trafficking, lipid modification, RNA processing and regulation, ubiquitin ligases, signaling, nuclear transport machinery, cytoskeleton, mitochondria, and extracellular matrix. SARS-CoV-2 proteins interact also with multiple innate immune pathways, affect host translation machinery, influence regulation of gene transcription (GORDON et al. 2020).

\section{IMMUNOPATHOLOGICAL CHANGES IN COVID-19}

The patients with COVID-19 have disturbance of immune system. Immunologic changes include alteration in the number and functioning of immune system cells. The infection can cause lymphopenia (cytotoxic $\mathrm{T}$ cell), eosinopenia, the increase of acute phase reactants, or disturbed $T$ cell response.

A large number of data suggest that pathogenesis of SARS-CoV-2 can be also related to cytokine storm syndrome, which is a systemic inflammatory response to pathogen antigens. COVID-19 infection showed increased levels of plasma proinflammatory mediators, including IL1- $\beta$, IL1RA, IL7, IL8, IL9, IL10, basic FGF2, G-CSF, GM-CSF, IFNy, IP10, MCP1, MIP1a, MIP1 $\beta$, PDGFB, TNFa, and VEGFA (HUANG et al. 2020). The cytokine storm is a major factor for disseminated intravascular coagulation and acute respiratory distress syndrome (ARDS). The latter triggers a damaging attack to the body causing failure of multiple organs and subsequently leads to death.

\section{RESERVOIRS AND TRANSMISSION OF CORONAVIRUSES}

The coronavirus infections have been reported in cattle, swine, horses, camels, rodents, cats, dogs, bats, palm civets, ferrets, minks, rabbits, snakes, and several other wild mammal and avian species (MALIK et al. 2020). All coronaviruses infecting human have zoonotic origin, and bats are most likely the natural hosts for all presently known human CoVs, including severe acute respiratory syndrome coronavirus (SARS-CoV)like and Middle East respiratory syndrome coronavirus (MERS-CoV)-like viruses (TIWARI et al. 2020).

SARS-CoV crossed the species barrier into palm civets and other animals in liveanimal markets in China. Several people in close proximity to palm civets became infected with SARS-CoV. A MERS-CoV ancestral virus crossed the species barrier into dromedary camels. Abundant circulation of MERS-CoV in dromedary camels results in frequent zoonotic transmission of this virus. After crossed the species barrier, SARS-CoV 


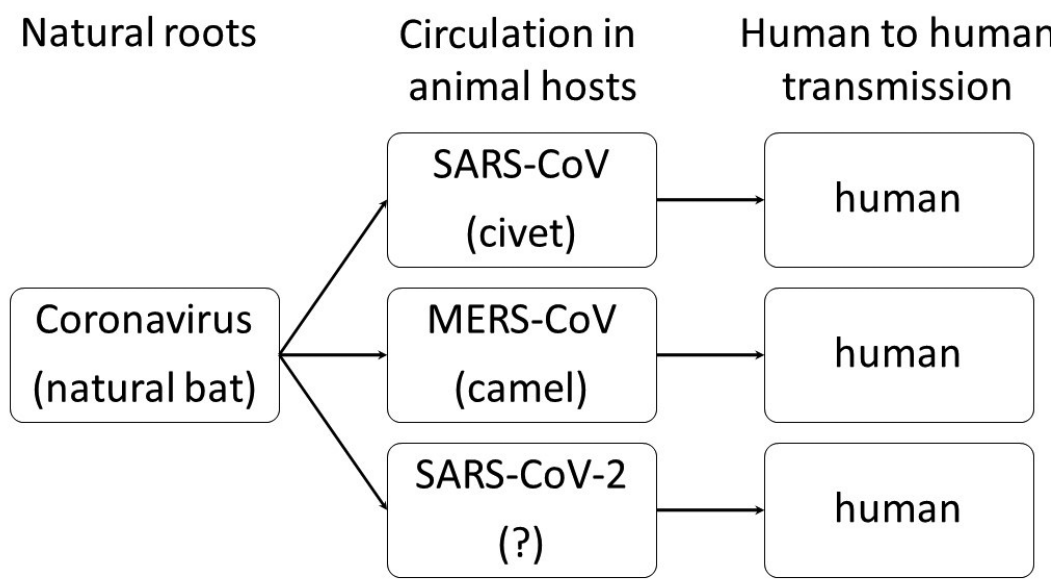

Figure 2. Ecology of emerging coronaviruses SARS-CoV, MERS-CoV and SARS-CoV-2. Arrows indicate the cross-species transmission.

and MERS-CoV spread between humans mainly through nosocomial transmission (Fig. 2). The exact origin of SARS-CoV-2 remains elusive, but in silico analysis suggests cross-species transmission (LAU et al. 2020).

The basic reproduction number for SARS-CoV-2 is currently estimated to be between 2 and 3 , the median incubation period is $6(2-14)$ days (SALZBERGER et al. 2020).

\section{TREATMENT OF COVID-19}

Currently, there are no specific antiviral drugs or vaccines for treatment of COVID-19. Agents previously used to treat SARS and MERS are potential candidates to treat COVID-19. Remdesivir, formally known as GS-5734, undergoes metabolism to an active C-adenosine nucleoside triphosphate analogue, which interferes with the viral RNAdependent RNA polymerase resulting in a decrease in viral RNA synthesis. Umifenovir is an antiviral agent with a unique mechanism of action targeting the $\mathrm{S}$ protein/ACE2 interaction and inhibiting membrane fusion of the viral envelope. Lopinavir/Ritonavir and other antiretroviral agents could be a putative protease inhibitors of SARS-CoV-2. These drugs display the in vitro activity against other coronaviruses via inhibition of 3-chymotrypsin-like protease. Chloroquine and hydroxychloroquine are anti malaria drugs. These agents could block viral entry into the cells by inhibiting glycosylation of host receptors, proteolytic processing, and endosomal acidification. These agents also have immunomodulatory effects through attenuation of cytokine production and inhibition of autophagy and lysosomal activity in the host cells. Type I IFNs are antiviral cytokines that induce a large range of proteins that can impair viral replication in targeted cells.

In the absence of an effective therapy for SARS-CoV-2, the cornerstone of care for patients with COVID-19 remains a supportive care. Three adjunctive therapies that warrant special mention are corticosteroids, anticytokine or immunomodulatory agents, and immunoglobulin therapy (SANDERS et al. 2020).

\section{CONCLUSION}

SARS-CoV-2 is an emerging human coronavirus causing a pandemic in 2020. In many aspects it appears to be similar to other coronaviruses: SARS-CoV and MERSCoV. Nevertheless some differences were observed concerning genome organization, protein structure and pathogenesis. These features may contribute to the wide spread of SARS-CoV-2. They may indicate the putative targets for specific antiviral therapy.

$$
\text { Streszczenie }
$$

W 2019 r. w Wuhan w Chinach pojawił się nowy ludzki koronawirus (SARS-CoV-2) wywołujacc pandemię. W niniejszej pracy przedstawiamy aktualny stan wiedzy na temat SARS-CoV-2, SARS-CoV i MERS-CoV, należących do Betakoronawirusów. Betakoronawirusy posiadaja osłonkę białkowo lipidowa, wewnątrz której znajduje się rybonukleokapsyd zawierajacy niesegmentowany jednoniciowy RNA o polarności dodatniej. SARS-CoV, MERS-CoV i SARS-CoV-2 sa wysoce patogennymi wirusami pochodzenia zoonotycznego. SARS-CoV-2 jest czynnikiem etiologicznym COVID-19, odpowiedzialnym za ogłoszona przez Światowa Organizację Zdrowia, pandemię w 2020 roku. Obecnie, nie sa dostępne skuteczne leki i szczepionki zapobiegające infekcjom spowodowanym przez omawiane wirusy. 


\section{REFERENCES}

BhaRdWAJ K., LiU P., LeIBOWITZ J. L., KaO C. C., 2012. The coronavirus endoribonuclease Nsp15 interacts with retinoblastoma tumor suppressor protein. J. Virol. 86, 4294-4304.

Bosch B. J., BARTELINK W., ROTTIER P. J., 2008. Cathepsin L functionally cleaves the severe acute respiratory syndrome coronavirus class I fusion protein upstream of rather than adjacent to the fusion peptide. J. Virol. 82, 88878890.

Chan J. F. W., KoK K. H., ZhU Z., ChU H., To K. K. W., YUAN S., YUEN K. Y., 2020. Genomic characterization of the 2019 novel human-pathogenic coronavirus isolated from a patient with atypical pneumonia after visiting Wuhan. Emerg. Microbes Infect. 9, 221-236.

Chang C. K., SuE S. C., YU T. H., Hsieh C. M., Tsai C. K., Chiang Y. C., Lee S. J., HsiaO H. H., Wu W. J., Chang W. L., Lin C. H., HuANG T. H., 2006. Modular organization of SARS coronavirus nucleocapsid protein. J. Biomed. Sci. 13, 59-72.

Coutard B., Valle C., De Lamballerie X., CANARD B., SEIDAH N. G., DECROLY E., 2020. The spike glycoprotein of the new coronavirus 2019-nCoV contains a furin-like cleavage site absent in CoV of the same clade. Antiviral Res. 176, 104742.

Devaraj S. G., Wang N., Chen Z., Tseng M., Barretto N., Lin R., Peters C. J., Tseng C. T., BAKER S. C., LI K., 2007. Regulation of $I R F-3-d e p e n d e n t$ innate immunity by the papain-like protease domain of the severe acute respiratory syndrome coronavirus. J. Biol. Chem. 282, 32208-32221.

DONG X., CAO Y. Y., LU X. X., ZHANG J. J., DU H., YAN Y. Q., AKDIS C. A., GAO Y. D., 2020. Eleven faces of coronavirus disease 2019. Allergy 20; $10.1111 /$ all.14289.

Escors D., ORTEGo J., LAUde H., EnJuanes L., 2001. The membrane $M$ protein carboxy terminus binds to transmissible gastroenteritis coronavirus core and contributes to core stability. J. Vir. 75, 1312-1324.

Gordon D. E., JANG G. M., Bouhaddou M., XU J., Obernier K., White K. M., O'MeAra M. J., REZELJ V. V., GUO J. Z., SWANEY D. L., TUMmino T. A., Huettenhain R., KaAke R. M., RICHARDS A. L., TUTUNCUOGLU B., FOUSSARD H., BATRA J., HAAS K., MODAK M., KIM M., HAAS P., Polacco B. J., BRABERG H., Fabius J. M., ECKHARDT M., SOUCHERAY M., BENNETT M. J., CAKIR M., McGRegor M. J., Li Q., MEYer B., RoEsch F., VAllet T., MaC Kain A., MiORIN L., MOREnO E., NAING Z Z. Z. C., ZHOU Y., PENG S. et al., 2020. A SARS-CoV-2 protein interaction map reveals targets for drug repurposing. Nature, doi.org/10.1038/s41586-020-2286-9.

Gu J., KorTEWEG C., 2007. Pathology and pathogenesis of severe acute respiratory syndrome. Am. J. Pathol. 170, 1136-1147.

Hoffmann M., Kleine-Weber H., Pöhlmann S., 2020a. A multibasic cleavage site in the spike protein of SARS-CoV-2 is essential for infection of human lung cells. Mol. Cell 78, 779-784. e 775 .

Hoffmann M., Kleine-Weber H., Schroeder S., KRÜGER N., HERRler T., ERICHSEN S., SCHIERGens T. S., Herrler G., Wu N. H., Nitsche A., MÜller M. A., Drosten C., PöhlmanN S., 2020b. SARS-CoV-2 cell entry depends on ACE2 and TMPRSS2 and is blocked by a clinically proven protease inhibitor. Cell 181, 271-280.
Huang C., Lokugamage K. G., Rozovics J. M., NARAYANAN K., SEMLER B. L., MAKINO S., 2011. SARS coronavirus nsp1 protein induces template-dependent endonucleolytic cleavage of mRNAs, viral mRNAs are resistant to nsp1-induced RNA cleavage. PLoS Pathog. 7, e1002433.

Huang C., Wang Y., Li X., Ren L., ZHaO J., HU Y., ZHANG L., FAN G., XU J., GU X., CHENG Z., YU T., XIA J., WeI Y., WU W., XIE X., YIN W., Li H., LIU M., XIAO Y., GaO H., GuO L., XIE J., WANG G., Jiang R., GaO Z., JiN Q., WANG J., CAO B., 2020. Clinical features of patients infected with 2019 novel coronavirus in Wuhan, China. Lancet 395, 497-506.

LaU S. Y., WANG P., MOK B. W., ZHANG A. J., Chu H., LeE A. C., Deng S., Chen P., Chan K. H., SONG W., Chen Z., TO K. K., CHAN J. F., YUEN K. Y., CHEN H., 2020. Attenuated SARS-CoV-2 variants with deletions at the S1/ S2 junction. Emerg. Microbes Infect. 9, 837842.

LI M. Y., LI L., ZHANG Y., WANG X. S., 2020a. Expression of the SARS-CoV-2 cell receptor gene ACE2 in a wide variety of human tissues. Infect. Dis. Poverty 9, 45.

Li Y., ZHOU W., YANG L., YOU R., 2020b. Physiological and pathological regulation of ACE2, the SARS-CoV-2 receptor. Pharmacol. Res. 157, 104833-104833.

LINDNER H. A., LYTVYN V., QI H., LACHANCE P., ZIOMEK E., MÉNARD R., 2007. Selectivity in ISG15 and ubiquitin recognition by the SARS coronavirus papain-like protease. Arch. Biochem. Biophys. 466, 8-14.

MALIK Y. S., SiRCAR S., BHAT S., SHARUN K., DHAMA K., DADAR M., TIWARI R., CHAICUMPA W., 2020. Emerging novel coronavirus (2019-nCoV)-current scenario, evolutionary perspective based on genome analysis and recent developments. Vet. Q. 40, 68-76.

MiNAKSHI R., PADHAN K., RANI M., KHAN N., AHMAD F., JAMEEL S., 2009. The SARS Coronavirus $3 a$ protein causes endoplasmic reticulum stress and induces ligand-independent downregulation of the type 1 interferon receptor. PLoS One 4, e8342.

Neuman B. W., Kiss G., Kunding A. H., Bhella D., BaKsh M. F., Connelly S., DROESE B., Klaus J. P., MaKino S., SaWicki S. G., SiDDEll S. G., Stamou D. G., Wilson I. A., KuHN P., BUCHMEIER M. J., 2011. A structural analysis of $M$ protein in coronavirus assembly and morphology. J. Struct. Biol. 174, 11-22.

OU X., LIU Y., LEI X., Li P., Mi D., REN L., GUO L., Guo R., Chen T., Hu J., Xiang Z., Mu Z., CHEN X., CHEN J., Hu K., JIN Q., WANG J., QIAN Z., 2020. Characterization of spike glycoprotein of SARS-CoV-2 on virus entry and its immune cross-reactivity with SARS-CoV. Nat. Commun. 11, 1620.

PARK S. E., 2020. Epidemiology, virology, and clinical features of severe acute respiratory syndrome-coronavirus-2 (SARS-CoV-2; Coronavirus Disease-19). Clin. Exp. Pediatr. 63, 119-124.

QIAN Z., DOMINGUEZ S. R., HOLMES K. V., 2013. Role of the spike glycoprotein of human Middle East respiratory syndrome coronavirus (MERS-CoV) in virus entry and syncytia formation. PLoS One 8, e76469.

Raj V. S., Mou H., SMits S. L., Dekkers D. H. W., MÜller M. A., DiJKMAN R., MUth D., DEMMERS J. A. A., ZAKI A., FOUCHIER R. A. M., Thiel V., Drosten C., RotTier P. J. M., Osterhaus A. D. M. E., Bosch B. J., HAAGMANS B. L., 2013. Dipeptidyl peptidase 4 is 
a functional receptor for the emerging human coronavirus-EMC. Nature 495, 251-254.

Reinke L. M., SPIEgel M., PlegGe T., HARTleib A., NEHLMEIER I., GIERER S., HOFFMANN M., HOFMANN-Winkler H., WinkleR M., PÖHLMANN S., 2017. Different residues in the SARS-CoV spike protein determine cleavage and activation by the host cell protease TMPRSS2. PLoS One 12, e0179177.

SALZBERGER B., BUDER F, LAMPL B, EHRENSTEIN B., HitzenBichleR F., HANSES F., 2020. Epidemiology of SARS-CoV-2 infection and COVID-19. Der Internist, 1-5.

Sanders J. M., Monogue M. L., Jodlowski T. Z., Cutrell J. B., 2020. Pharmacologic Treatments for Coronavirus Disease 2019 (COVID-19), A Review. JAMA 323, 1824-1836.

SCHOEMAN D., FIELDING B. C., 2019. Coronavirus envelope protein, current knowledge. J. Virol. $16,69$.

Shang J., Wan Y., Luo C., Ye G., Geng Q., AuERBACH A., LI F., 2020. Cell entry mechanisms of SARS-CoV-2. Proc. Natl. Acad. Sci. USA $117,11727-11734$

Sigrist C. J., BRIDGe A., LE Mercier P., 2020. A potential role for integrins in host cell entry by SARS-CoV-2. Antiviral Res 177, 104759.

Simmons G., Gosalia D. N., REnNEKamp A. J., REEVES J. D., DiAMOND S. L., BATES P., 2005. Inhibitors of cathepsin $L$ prevent severe acute respiratory syndrome coronavirus entry. Proc. Natl. Acad. Sci. USA 102, 11876-11881.

SiU K. L., KOK K. H., NG M. H., POON V. K., YUEN K. Y., ZHENG B, J, Jin D. Y, 2009. Severe acute respiratory syndrome coronavirus $M$ protein inhibits type I interferon production by impeding the formation of TRAF3.TANK.TBK1/ IKKepsilon complex. J. Biol. Chem. 284, 16202-16209.

SNiJder E. J., VAN DER MEeR Y., ZEVENHOVEN-DOBBE J., ONDERWATER J. J. M., VAN DER Meulen J., Koerten H. K., Mommaas A. M., 2006. Ultrastructure and origin of membrane vesicles associated with the severe acute respiratory syndrome coronavirus replication complex. J. Virol. 80, 5927.

SUBISSI L., IMBERT I., FERRON F., COllet A., COUTARD B., DECROLY E., CANARD B., 2014. SARS-CoV ORF1b-encoded nonstructural proteins 12-16, replicative enzymes as antiviral targets. Antiviral Res. 101, 122-130.

TANG T. K., WU M. P. J., CHEN S. T., HOU M. H., HONG M. H., PAN F. M., YU H. M., CHEN J. H., YaO C. W., Wang A. H. J., 2005. Bio chemical and immunological studies of nucle- ocapsid proteins of severe acute respiratory syndrome and 229E human coronaviruses. Proteomics 5, 925-937.

Tiwari R., DHAMa K., SHaRUn K., IOBal Yatoo M., MaliK Y. S., Singh R., MichalaK I., SAH R., BONILlA-AlDANA D. K., RODRIGUEZ-MORALES A. J., 2020. COVID-19, animals, veterinary and zoonotic links. Vet. Q. 40, 169-182.

VAN DOREMalen N., Bushmaker T., MORRIS D. H., HolbrooK M. G., Gamble A., Williamson B. N., TAMIN A., HARCOURT J. L., THORNBURG N. J., Gerber S. I., LlOYd-Smith J. O., DE WIT E., Munster V. J., 2020. Aerosol and surface stability of SARS-CoV-2 as compared with SARS-CoV-1. N. Engl. J. Med. 382, 15641567.

Vennema H., Godeke G. J., Rossen J. W., VoORHOUT W. F., HORZINEK M. C., Opstelten D. J., ROTTIER P. J., 1996. Nucleocapsid-independent assembly of coronavirus-like particles by co-expression of viral envelope protein genes. EMBO J. 15, 2020-2028.

WAlls A. C., PARK Y. J., TORTORICI M. A., WALL A., MCGUiRe A. T., VeEsler D., 2020. Structure, function, and antigenicity of the SARS -CoV-2 spike glycoprotein. Cell 181, 281-292.

WANG H., YANG P., LiU K., GUO F., ZHANG Y., ZHANG G., JIANG C., 2008. SARS coronavirus entry into host cells through a novel clathrinand caveolae-independent endocytic pathway. Cell. Res. 18, 290-301.

Watanabe Y., Allen J. D., Wrapp D., MClellan J. S., CRISPIN M., 2020. Site-specific glycan analysis of the SARS-CoV-2 spike. Science, eabb9983.

Xu Z., SHI L., WANG Y., ZHANG J., HuANG L., Zhang C., LiU S., ZhaO P., LiU H., ZhU L. TAI Y., BAI C., GaO T., SONG J., XIA P., Dong J., ZHAO J., WANG F. S., 2020. Pathological findings of COVID-19 associated with acute respiratory distress syndrome. Lancet Respir. Med. 8, 420-422.

Zeng W., LiU G., Ma H., Zhao D., Yang Y., LiU M., Mohammed A., ZHAO C., Yang Y., XIE J., Ding C., MA X., WENG J., GAO Y., HE H., JIN T., 2020. Biochemical characterization of SARS-CoV-2 nucleocapsid protein. Biochem. Biophys. Res. Commun. 527, 618-623.

ZHENG J., 2020. SARS-CoV-2, an emerging coronavirus that causes a global threat. Int. J. Biol. Sci. 16, 1678-1685. 
KOSMOS Vol. 69, 2, 277-285, 2020

\section{AGNIESZKA KWIATEK}

Department of Molecular Virology, Institute of Microbiology, Faculty of Biology, Warsaw University, 1 Miecznikowa Str., 02-096 Warsaw, E-mail: akwiat@biol.uw.edu.pl

\section{PROPERTIES AND PATHOGENESIS OF CORONAVIRUSES}

\section{Summary}

In 2019, a new human pandemic coronavirus (SARS-CoV-2) has emerged in Wuhan, China. We present the actual state of knowledge on Betacoronaviruses, including data on SARS-CoV-2, SARS-CoV and MERS-CoV. Betacoronaviruses are enveloped viruses with nonsegmented, positive-sense single-stranded RNA genome. SARS-CoV, MERSCoV, and SARS-CoV-2 are highly pathogenic zoonotic viruses. SARS-CoV-2 is an etiological factor of COVID-19, which has been brought to global attention and declared a pandemic by the World Health Organization in 2020. The SARS-CoV-2 is similar to other coronaviruses, nevertheless some differences were observed. As no specific therapeutics and vaccines are available for disease control, the epidemic of COVID-19 is posing a great threat for the global public health. 